\title{
Dorota Kałuża-Kopias*
}

\section{POLSCY EMIGRANCI W PÓŹNYM WIEKU}

Streszczenie. Celem niniejszego opracowania jest rozpoznanie skali emigracji starszych mieszkańców Polski w XXI wieku. Na wstępie przedstawiono wypracowane w literaturze przedmiotu koncepcje wyjaśniające mechanizmy migracji seniorów. Analizując rzeczywiste przemieszczenia seniorów, skupiono się głównie na pokazaniu skali emigracji oraz głównych kierunków przemieszczeń. Analiza została oparta o dane dotyczące emigracji na stałe z kraju w latach $2002-$ 2013 dostępne na stronie Głównego Urzędu Statystycznego (GUS). Wyniki analizy wskazują, że starsi Polacy stanowią niewielki, względnie stały w ostatnich latach odsetek emigrantów. Emigrujący seniorzy to najczęściej osoby będące w związkach małżeńskich, charakteryzujący się niskim poziomem wykształcenia.

Słowa kluczowe: migracje osób starszych, demografia, emigracja.

\section{Wstęp}

Charakterystyczną cechą współczesnych przemian ludnościowych w krajach, które osiągnęły fazę dojrzałości demograficznej, jest proces starzenia się populacji. Liczba ludności w wieku 65 lat i więcej w 1950 r. w Polsce stanowiła około 6\% ogólnej liczby ludności kraju, zaś w latach 1990. odsetek ten wzrósł do blisko 12\%. W 2013 r. udział osób powyżej 65. roku życia stanowił już prawie $15 \%$ ogółu ludności Polski. Według prognoz GUS do 2050 r. odsetek osób starszych (65 lat i więcej) wzrośnie do poziomu 33\%. W związku z tym rozpoznanie zachowań i potrzeb osób starszych stanowiło i stanowi przedmiot zainteresowania badaczy wielu dziedzin nauki, m.in. demografii (Rosset 1959, Szukalski 2002, Kowaleski, Szukalski 2011). Jednym z procesów demograficznych są migracje ludności. Na decyzję o przeprowadzce ma wypływ wiele grup czynników społecznych, psychologicznych i ekonomicznych, które oddziaływują $\mathrm{z}$ różną siłą, m.in. w zależności od wieku osób uczestniczących w ruchu wędrówkowym (Latuch 1977, Stolarczyk 1985, 1986, Charles, Longino 2001, Quandango 2002, Kałuża-Kopias, 2006, 2008, 2011). W przypadku ludności starszej zjawisko migracji jest procesem specyficznym, który nie podlega tym samym prawidłowościom, co przemieszczenia ludzi młodych. Ludzie starzy z natury niechętnie zmieniają wieloletnie miejsce zamieszkania. Często akt

\footnotetext{
* Dr, Zakład Demografii i Gerontologii Społecznej Uniwersytetu Lódzkiego.
} 
migracji ma charakter wymuszony i związany jest z zapewnieniem opieki osobie w podeszłym wieku.

Celem niniejszego opracowania jest rozpoznanie skali emigracji starszych mieszkańców z Polski w XXI wieku. Na wstępie przedstawiono wypracowane w literaturze przedmiotu koncepcje wyjaśniające mechanizmy migracji seniorów. W tym celu dokonano przeglądu literatury obcojęzycznej, tak teoretycznej, jak i empirycznej, związanej z mobilnością przestrzenną tej subpopulacji. Opis koncepcji teoretycznych, ograniczony do przedstawienia głównych założeń, ma ułatwić zrozumienie mechanizmów migracji na różnych etapach starości. Analizując rzeczywiste przemieszczenia seniorów, skupiono się głównie na pokazaniu skali emigracji oraz głównych kierunków przemieszczeń. Analiza została oparta o dane, dotyczące emigracji na stałe z kraju w latach 2002-2013, dostępne na stronie Głównego Urzędu Statystycznego, w bazie Demografia: http://demografia.stat.gov.pl/bazademografia/.

W niniejszym opracowaniu za emigranta w późnym wieku przyjęto osobę, która ukończyła 65. rok życia. Ponieważ na różnych etapach starości kluczową rolę odgrywają inne motywy i przyczyny w procesie podejmowania decyzji o zmianie miejsca zamieszkania, wśród seniorów wydzielono podgrupy. Pierwszą z nich stanowią osoby, które nie ukończyły 70. roku życia - pozostają one najczęściej w związkach małżeńskich, a głównym motywem przeprowadzki w ich przypadku jest chęć poprawy komfortu życia. Drugą grupę stanowią seniorzy, którzy ukończyli 70 lat, w przypadku, tej grupy utrata współmałżonka przekłada się często na zmniejszenie dochodów i staje się głównym bodźcem do przeprowadzki, a w wraz z dochodzeniem do coraz wyższego wieku, migracja często ma charakter wymuszony złym stanem zdrowia uniemożliwiającym samodzielne funkcjonowanie.

\section{Wybrane koncepcje wyjaśniające migracje osób starszych}

W ostatnim trzydziestoleciu, w literaturze zachodniej powstało wiele opracowań dotyczących przemieszczeń osób starszych (m.in. Cuba i Longino, 1991; Meyer, 1987; Rogers 1990; Serow 1987; Wiseman, 1980; Quandango 2002, Walters 2006, Uren, Goldring 2007, La Parra, Mateo, 2008), co odzwierciedlało wzrost skali przemieszczeń osób starszych. W niniejszym paragrafie, szerzej zostały omówione koncepcje związane z teoriami: czynników „push” i „pull”, cyklu życia, rozwoju decyzji o przeprowadzce, utracie czy też braku równowagi domowej, utożsamianiu się z miejscem zamieszkania oraz migracjach związanych z instytucjonalizacją starości.

Jednym z najbardziej znanych podejść do wyjaśnienia decyzji o migracji osób starszych jest koncepcja bazująca na tzw. czynnikach „push” i „pull” (wypychania i przyciągania) (Wiseman;1980: 143) (rys.1). W podejściu tym czynni- 
kami, które mogą wpływać na decyzje o migracji, są: a) zmiany cyklu życia rodziny (np. odejście $\mathrm{z}$ domu dzieci czy przejście na emeryturę), b) związane $\mathrm{z}$ wiekiem występowanie niepełnosprawności, c) krytyczne zdarzenia w życiu seniorów (śmierć współmałżonka). Z kolei, czynniki te można podzielić na czynniki sprzyjające migracji (np. utrata współmałżonka, występujący stres w miejscu zamieszkania) i czynniki powstrzymujące przeprowadzkę (np. bliskość krewnych i znajomych czy uczestnictwo w życiu wspólnoty).

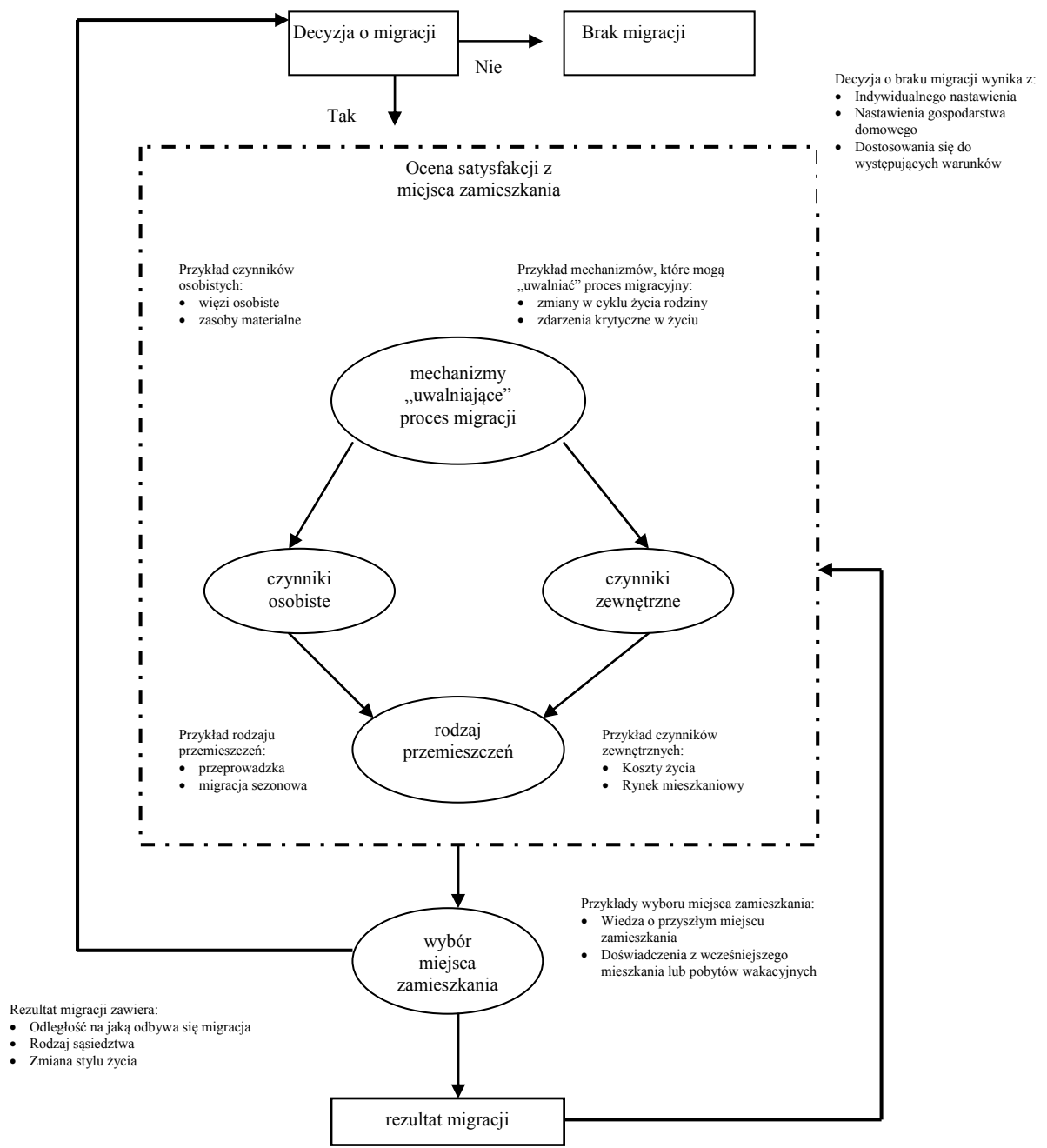

Rysunek 1. Teoretyczny model migracji seniorów

Źródło: (Lawrence, Schiamberg, Kathleen, McKinney, 2003: 5). 
Ponadto wpływ na decyzje migracyjne mają czynniki osobiste (np. zasoby materialne, poprzednie doświadczenia migracyjne, osobiste więzi), jak również czynniki zewnętrzne (np. koszty utrzymania), które mogą utrudniać lub ułatwiać migrację. Według Wisemana wybór miejsca przyszłego zamieszkania dokonywany jest dopiero, gdy zostanie podjęta już decyzja o przeprowadzce. Haas i Serow (1993: 112-120) dostosowali propozycję Wisemana do potrzeb analizy migracji osób, które przeszły na emeryturę. W tym celu wprowadzili do swej koncepcji, jako czynniki migracyjne: „dalekie myśli” (marzenia o przeprowadzce), które poprzedzają przeprowadzkę oraz źródła informacji, które sprawiają że potencjalny migrant ma świadomość występowania czynników wypychających i przyciągających. Kolejnym, ważnym uzupełnieniem koncepcji Wisemana jest uwzględnienie jako motywu migracyjnego relacji i więzi występujących w społeczności lokalnej w miejscu zamieszkania migranta. Koncepcja HaasaSerowa sprawdziła się w analizie emerytowanych migrantów międzystanowych do Idaho.

Kolejna grupa koncepcji migracji osób starszych oparta została na teorii przebiegu (cyklu) życia (the life-course), która zakłada, że przebieg migracji jest związany $\mathrm{z}$ pewnymi zdarzeniami występującymi w poszczególnych fazach życia człowieka oraz prawdopodobieństwami ich zajścia. Zdarzeniami, które mogą prowadzić do migracji, są, m.in.: zawarcie małżeństwa ${ }^{1}$, powiększenie się rodziny (pojawienie się dzieci) ${ }^{2}$, moment opuszczenia domu przez dorosłe już dzieci $^{3}$ lub przejście na emeryturę. Zakończenie kariery zawodowej jest zdarzeniem, które prowadzić może do przeprowadzki. Ten rodzaj migracji przypada na etap życia seniorów, w którym zazwyczaj są oni zamężni/żonaci, stosunkowo zdrowi oraz posiadają względnie wysokie dochody z tytułu emerytury w porównaniu ze średnim poziomem zarobków. W literaturze anglosaskiej migracje emerytalne doczekały się wielu opracowań (m.in. Breure, 2005, Warnes i in., 1999, 2004). Większość z tych przemieszczeń, opisanych w literaturze, to migracje z północno-zachodnich krajów europejskich na południe Europy. Przykładowo, Breuer (2005: 321) twierdzi, że w przypadku starszych Niemców, którzy kierują się na Wyspy Kanaryjskie, migracje emerytalne nie prowadzą do trwałej zmiany zamieszkania, lecz jest to „wydhużona” forma turystyki, tzw. przeprowadzka do drugiego domu na pewien okres. Ten rodzaj przemieszczeń, według przywoływanego Autora, jest wynikiem chęci zapewnienia sobie na stare lata odrobiny przyjemności. Brytyjczycy na emeryturze wybierają następujące kierunki migra-

\footnotetext{
${ }^{1}$ Które zawsze związane jest ze zmianą miejsca zamieszkania jednego lub obojga współmałżonków, o ile nie mieszkali przedtem razem.

${ }^{2} \mathrm{O}$ ruchliwości na tym etapie życia świadczy znaczny udział dzieci w wieku do sześciu lat wśród migrantów.

${ }^{3}$ Największą częstością migracji charakteryzują się osoby w wieku 20-29 lat. Jest to wiek odbywania studiów, rozpoczynania kariery zawodowej i wstępowania w związek małżeński.
} 
cji: Włochy (w szczególności Toskania), Malta, Hiszpania (Costa del Sol) i Portugalii (region Algarve). Wszystkich tych starszych migrantów łączy jedno mają wyższe od średnich emerytury, są mieszkańcami większych miast (Warnes $\mathrm{i}$ in., 2004: 312).

Na początku lat 1990. wiele uwagi poświęcono koncepcji braku równowagi w miejscu zamieszkania (the housing disequilibrium) w kontekście przeprowadzek osób starszych. Koncepcja ta bazowała na założeniu, że główną motywację emerytów do zmiany miejsca zamieszkania stanowią koszty utrzymania mieszkania. Względny - wobec spadku dochodów - wzrost obciążeń finansowych związanych z eksploatacją mieszkania stanowi bodziec do przeprowadzki z obszarów centralnych miast na tańsze obszary podmiejskie. Hogan i współautorzy (1992: 246-260) postawili hipotezę, że migracja osób starszych do Arizony, zarówno sezonowa, jak i stała, wynikają w części z różnic w cenie mieszkań na obszarach obecnego i przyszłego zamieszkania. Na przykład, sprzedając dom w Kalifornii, można kupić mieszkanie lub dom za niższą kwotę w nowym miejscu, a pozostałą część dochodów odłożyć lub przeznaczyć na bieżącą konsumpcje.

Jedną z koncepcji powstałych w latach 1990. nazwano modelem tożsamości miejsca (the place identity model). Każda przeprowadzka wiąże się z zamieszkaniem wśród nowej społeczności. Jednak fizyczna zmiana miejsca zamieszkania niekoniecznie musi oznaczać, że ktoś przeprowadził się emocjonalnie. Są migranci, którzy nigdy nie zapuszczą korzeni, ponieważ pozostają emocjonalnie związani z społecznościami, w których żyli wcześniej przez dekady. Cuba i Hummon (1993: 111-131) dowodzą, że identyfikacja z jakimś miejscem zamieszkania i ze społecznością rozumiana jest odmiennie na różnych etapach życia. Młodsi migranci częściej opierają swoją tożsamość na przynależności do sieci przyjaciół, rodziny oraz na emocjonalnej samoprzynależności, podczas gdy starsi migranci budują ją na podstawie wcześniejszych doświadczeń, jakie nabyli w danym miejscu. Tak naprawdę tożsamość miejsca ulega zmianom przez całe nasze życie i doświadczenie, jakie w jego ciągu zdobywamy. Dlatego też tożsamość na różnych etapach starości może stanowić istotny czynnik wpływający na decyzje o przeprowadzce.

Nowym obszarem badań migracji osób w starszym wieku są przemieszczenia związane $\mathrm{z}$ opieką instytucjonalną, tzn. migracje do domów opieki (migration to nursing homes). Ten rodzaj migracji pojawia się, kiedy osoby starsze a z reguły bardzo stare - stają się chore, wymagają opieki lub zostają samotne. Ograniczony zasób najbliższych krewnych i stopień niepełnosprawności, który uniemożliwia samodzielną egzystencję, jest głównym powodem przeprowadzki. Większość takich migracji odbywa się raczej na krótkie niż dalekie dystanse. McAuley, Pechioni i Grant (za: Quandango 2002: 120) badając migracje seniorów w kontekście opieki instytucjonalnej, porównali odległość przeprowadzek oraz cechy migrantów, którzy kierowali się do domów opieki w Wirginii. Większość 
pensjonariuszy pochodziła $\mathrm{z}$ tego samego stanu. Autorzy cytowanego badania założyli, że niska dostępność łóżek w domach opieki w hrabstwie, z którego pochodzą mieszkańcy domu opieki, jest czynnikiem popychającym do przeprowadzki na większy dystans. Dodatkowym czynnikiem przyciągającym do domów opieki w Wirginii był ich związek z Kościołem. Religijna przynależność osób starszych i ich lojalność wobec Kościoła, który wspierali finansowo przez wiele lat, prawdopodobnie przyciągała pensjonariuszy z innych hrabstw. Colsher i Wallache (1990: 12), badając przeprowadzki starszej ludności wiejskiej, porównali przemieszczenia seniorów kierujących się do domów opieki z pozostałymi kierunkami migracji. W obu przypadkach przemieszczeń występował wysoki udział przeprowadzek mających związek ze zdrowiem, zatem - według autorów - przeprowadzki mające związek ze zdrowiem w późnym okresie życia nie do końca wiążą się z instytucjonalizacją starości.

\section{Skala i kierunki emigracji po 65. roku życia z Polski}

Początek $X X I$ wieku przyniósł nasilenie emigracji z Polski, a momentem kulminacyjnym był rok 2006, w którym wyjechało z Polski na stałe blisko 48 tys. mieszkańców, co stanowiło 12,5 osoby na 10 tys. mieszkańców kraju. W wyniku kryzysu gospodarczego w krajach Europy Zachodniej, w kolejnych latach nastąpiło ograniczenie wyjazdów za granice. Od 2010 roku widoczne jest ponowne ożywienie emigracji z kraju (rys. 2). Z roku na rok rośnie liczba emigrantów, a w 2013 r. natężenie emigracji z Polski wyniosło około 9 osób na 10 tys. ludności. Przyglądając się strukturze wieku emigrantów, nie trudno zauważyć, że największą grupę wśród wyjeżdżających stanowią osoby młode (najczęściej między 20. a 34. rokiem życia).

Udział wśród emigrantów osób po 65. roku życia nie jest duży (średnio rocznie $3,7 \%$ ogółu emigrantów w analizowanym okresie) i przez ostanie dwanaście lat nie zmieniał się w sposób znaczący. W 2013 r. wyjechało z Polski na stałe prawie 3 seniorów na 10000 ludności w wieku 65. lat i więcej. Wśród starszych emigrantów przeważają „,młodsi seniorzy”, którzy nie ukończyli 70. roku życia. Ostatni rok analizy charakteryzował się największą intensywnością wyjazdów emigrantów w wieku 65-69 lat (5,3 osoby starszej na 10000 ludności w wielu 65-69 lat) (rys. 3). W przypadku seniorów po 70. roku życia, natężenie emigracji wśród tej subpopulacji między 2002 a 2013 rokiem nie przekraczało 2 osób na 10000 mieszkańców Polski w tym wieku, za wyjątkiem 2002 r., w którym natężenie wyjazdów na stałe tych seniorów wyniosła 2,3 osoby na 10000 mieszkańców Polski w tym wieku. 


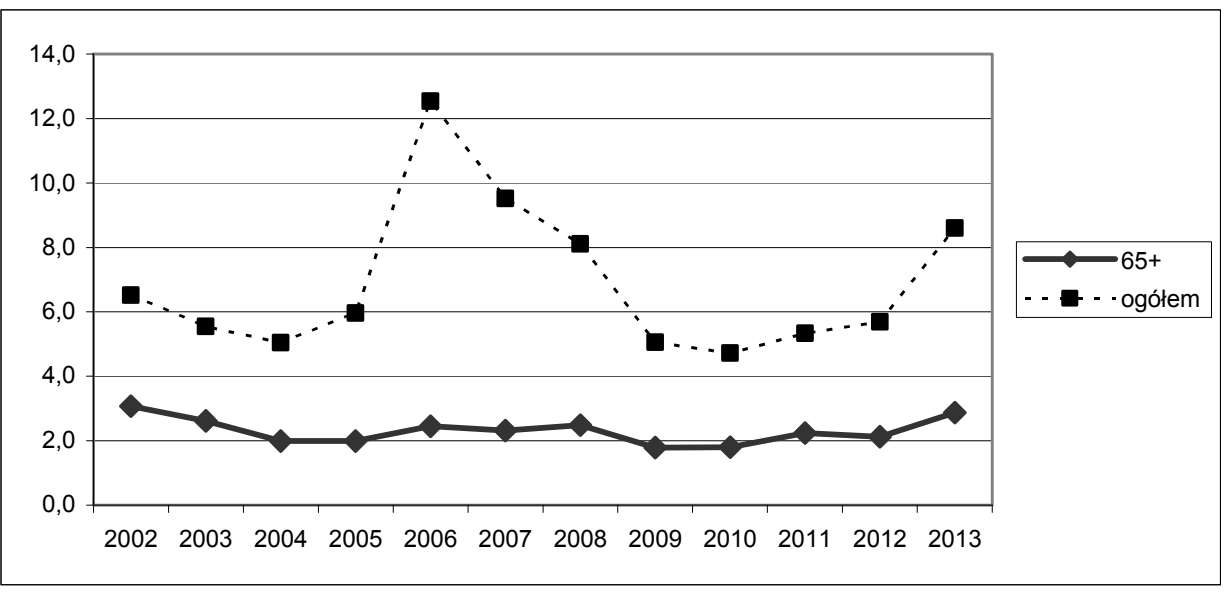

Rysunek 2. Natężenie emigracji na stałe z Polski w latach 2002-2013 (na 10000 ludności) Źródło: Opracowanie własne na podstawie bazy danych Demografia.

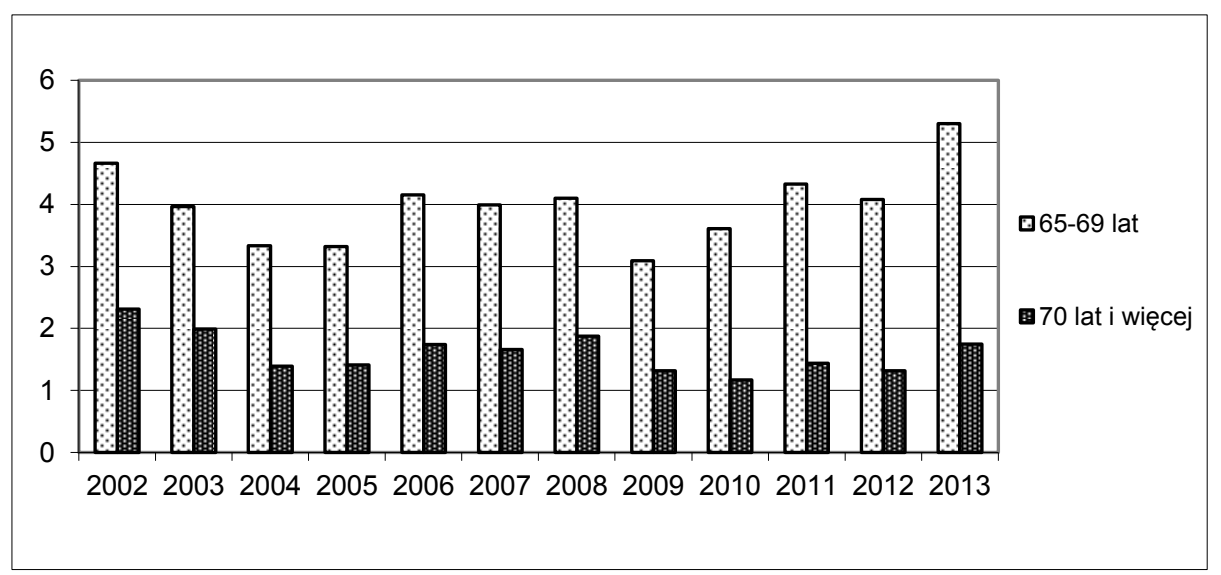

Rysunek 3. Natężenie emigracji wśród seniorów w latach 2002-2013 (osób na 10000 ludności w danym wieku)

Źródło: Opracowanie własne na podstawie bazy danych Demografia.

Od 2009 r. w bazie Demografia (GUS) dostępne są informacje odnośnie do wieku i kierunków przemieszczeń zagranicznych. Jak wynika $\mathrm{z}$ tych danych, starsi emigranci znacznie częściej niż osoby młode (w wieku 20-34 lat) brali udział w przemieszczeniach poza kontynent. W latach 2002-2013 około 90\% wyjeżdżających na stałe osób w wieku 20-34 lata osiedlało się w Europie, zaś w przypadku osób po 65 roku życia udział ten w tym okresie wahał się między $75 \%$ a $80 \%$. Szansa wystąpienia przeprowadzki po za Europę w przypadku osoby 
po 65 roku życia była 1,7 razy większa niż w przypadku generacji w wieku 2034 lata $^{4}$. Emigranci po 65 roku częściej niż osoby młode jako kraj osiedleńczy wybierali Niemcy i Stany Zjednoczone Ameryki niż Wielką Brytanię (rys. 4). W 2013 r. 58\% wszystkich seniorów (w wieku 65 lat i więcej) wyjeżdżających na stałe z Polski, jako kraj docelowy wybierało Niemcy, a jedynie niespełna $6 \%$ kierowało się do Wielkiej Brytanii. Dla porównania wśród emigrantów w wieku 2529 lat, 35\% migrowało na stałe do Niemiec, a 30\% do Wielkiej Brytanii.

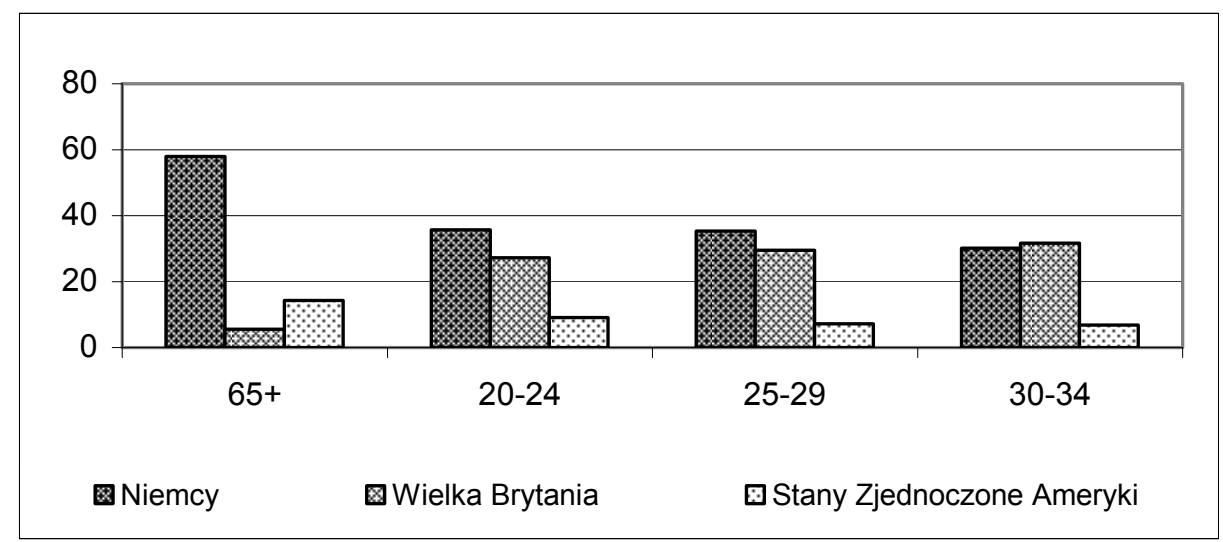

Rysunek 3. Główne kraje emigracji na stałe z Polski według wybranych grup wieku w latach 2009-2013 (w \% ogółu średniego poziomu emigracji w latach 2002-2013)

Źródło: Opracowanie własne na podstawie bazy danych Demografia.

${ }^{4}$ Szacując szansę przeprowadzki seniora po za Europę posłużono się metodą „odds ratio”. Pojęcie szansa odnosi się do ilorazu prawdopodobieństwa zajścia zdarzenia (np. migracji), do prawdopodobieństwa, że to zdarzenie nie wystąpi. Metoda „odds ratio" polega na porównaniu dwóch grup (1 - grupa, u której zaszła migracja, 2 - grupa, u której do migracji nie doszło). W rezultacie uzyskujemy informację o ilorazie prawdopodobieństw zmiany statusu przez jednostki wchodzące w skład dwóch porównywalnych subpopulacji

$$
O R_{A \times B}=\frac{S(A)}{S(B)}=\frac{P(A)}{1-P(A)} \div \frac{P(B)}{1-P(B)}
$$

gdzie: $O R_{A \times B}$ - iloraz szans (odds ratio); $A$ - grupa A; $B$ - grupa B; $P(A)$ - wystąpienie zdarzenia w grupie $\mathrm{A} ; P(B)$ - wystąpienie zdarzenia w grupie $\mathrm{B} ; S(A)$ - szansa wystąpienia zdarzenia w grupie A (stosunek wystąpienia zdarzenia do niewystąpienia zdarzenia); $S(B)$ - szansa wystąpienia zdarzenia w grupie B (stosunek wystąpienia zdarzenia do niewystąpienia zdarzenia); Jeżeli $O R \approx 1$ oznacza to, że szansa wystąpienia zdarzenia w jednej i drugiej grupie jest podobna.

Jeżeli $O R<1$ oznacza to, że w badanej grupie (w porównaniu do grupy odniesienia) istnieje mniejsza szansa wystąpienia zdarzenia.

Jeżeli $O R>1$ oznacza to, że w badanej grupie (w porównaniu do grupy odniesienia) istnieje większa szansa wystąpienia danego zdarzenia. 
Wskazuje to, iż starsi emigranci kontynuują wyjazdy do Niemiec, które to $\mathrm{w}$ okresie transformacji były dominującym kierunkiem emigracji z Polski. W przypadku młodszych generacji urodzonych w połowie lat 1970. i 1980 ., akcesja Polski do UE spowodowała otworzenie nowych rynków pracy, co w powiązaniu ze złą sytuacją na rodzimym rynku pracy zwłaszcza dla absolwentów szkół średnich i wyższych zaowocowało wytworzeniem nowych sieci migracyjnych, które przyciągały głównie ludzi młodych do krajów takich, jak Wielka Brytania i Irlandia. Krótko mówiąc, emigracja do Niemiec (oraz USA) jest obecnie, znacznie starsza niż migracja do Wielkiej Brytanii (oraz Irlandii).

\section{Wybrane charakterystyki demograficzne emigrantów po 65. roku życia}

Przyglądając się strukturze starszych migrantów ze względu na płeć (tab. 1) można zauważyć, że między 2002 a 2013 rokiem wzrósł udział kobiet wśród emigrantów po 65 roku życia. Obecnie (2013 r.) odsetek starszych kobiet wśród emigrantów po 65 roku życia wynosi $61,4 \%$. Liczebna przewaga kobiet utrzymywała się również w miarę przesuwania się do coraz starszych grup wieku.

Tablica 1. Udział kobiet i mężczyzn po 65. roku życia w emigracji w latach 2002 i 2013 (w \%)

\begin{tabular}{|l|c|c|c|c|c|c|}
\hline \multirow{2}{*}{ Wiek } & \multicolumn{3}{|c|}{2002} & \multicolumn{3}{c|}{2013} \\
\cline { 2 - 7 } & ogółem & mężczyźni & kobiety & ogółem & mężczyźni & kobiety \\
\hline 65-69 & 100 & 51,5 & 48,5 & 100 & 51,3 & 48,7 \\
\hline 70 lat i więcej & 100 & 31,8 & 68,2 & 100 & 40,9 & 59,1 \\
\hline 65 lat i więcej & 100 & 41,2 & 58,8 & 100 & 38,6 & 61,4 \\
\hline
\end{tabular}

Źródło: Opracowanie własne na podstawie bazy danych Demografia.

W przeciwieństwie do migracji wewnętrznych, w których przeważały osoby samotne (Kałuża, 2008: 158), wśród starszych emigrantów większość stanowiły osoby pozostające w związkach małżeńskich (tab. 2). Na kolejnych miejscach znalazły się osoby owdowiałe, rozwodnicy oraz kawalerowie i panny. Wyraźna przewaga kobiet wśród starszych emigrantów występowała wśród osób owdowiałych. Warto zaznaczyć, że w latach 2002-2013, zwiększył się udział rozwodników. 
Tablica 2. Emigranci po 65 roku życia według stanu cywilnego w latach 2002,2005, 2008, 2011, 2013 (w \% ogółu imigrantów po 65 roku życia)

\begin{tabular}{|c|c|c|c|}
\hline \multirow{2}{*}{ Stan cywilny } & \multicolumn{3}{|c|}{$2002 \mathrm{r}}$. \\
\hline & ogółem & mężczyźni & kobiety \\
\hline Kawaler/panna & 2,7 & 3,1 & 2,6 \\
\hline Żonaty/zamężna & 53,0 & 75,3 & 37,1 \\
\hline wdowiec/wdowa & 30,2 & 10,4 & 42,5 \\
\hline \multirow[t]{2}{*}{ rozwiedziony/rozwiedziona } & 3,5 & 2,8 & 3,9 \\
\hline & \multicolumn{3}{|c|}{$2005 \mathrm{r}$. } \\
\hline Kawaler/panna & 2,6 & 2,9 & 2,3 \\
\hline Żonaty/zamężna & 53,8 & 72,5 & 42,5 \\
\hline wdowiec/wdowa & 29,6 & 10,4 & 41,3 \\
\hline \multirow[t]{2}{*}{ rozwiedziony/rozwiedziona } & 4,0 & 4,2 & 3,9 \\
\hline & \multicolumn{3}{|c|}{$2008 \mathrm{r}$. } \\
\hline Kawaler/panna & 3,0 & 3,2 & 2,8 \\
\hline Żonaty/zamężna & 58,6 & 70,5 & 49,1 \\
\hline wdowiec/wdowa & 17,7 & 6,2 & 26,8 \\
\hline \multirow[t]{2}{*}{ rozwiedziony/rozwiedziona } & 5,1 & 5,3 & 5,0 \\
\hline & \multicolumn{3}{|c|}{$2011 \mathrm{r}$. } \\
\hline Kawaler/panna & 3,3 & 2,0 & 3,6 \\
\hline Żonaty/zamężna & 54,3 & 72,8 & 43,8 \\
\hline wdowiec/wdowa & 23,4 & 7,1 & 32,8 \\
\hline \multirow[t]{2}{*}{ rozwiedziony/rozwiedziona } & 7,0 & 5,4 & 7,9 \\
\hline & \multicolumn{3}{|c|}{$2013 \mathrm{r}$. } \\
\hline Kawaler/panna & 3,1 & 3,6 & 2,8 \\
\hline Żonaty/zamężna & 58,5 & 73,2 & 49,3 \\
\hline wdowiec/wdowa & 23,0 & 9,5 & 31,5 \\
\hline rozwiedziony/rozwiedziona & 8,6 & 6,7 & 9,9 \\
\hline
\end{tabular}

Źródło: Opracowanie własne na podstawie bazy danych Demografia.

Kolejną z omawianych charakterystyk jest poziom wykształcenia osób uczestniczących w emigracji. Informacje o tej charakterystyce zbierane były podczas Narodowych Spisów Ludności zarówno w 2002 r., jak i w 2011. Jednak dane odnośnie do poziomu wykształcenia dotyczyły okresu w momencie spisu nie zaś w chwili emigracji. W przypadku analizowanej subpopulacji osób po 65 roku życia przyjęto, że poziom wykształcenia w momencie spisu pokrywał się $\mathrm{z}$ poziomem $\mathrm{w}$ chwili wyjazdu. Ponadto, w przypadku poziomu wykształcenia emigrantów, odnotowano - szczególnie podczas spisu z 2011 r. - bardzo wysoki odsetek nieustalonego poziomu wykształcenia. Należy zatem podejść do interpretacji tych danych z ostrożnością (tab. 3). 
Tablica 3. Emigranci po 65 roku życia według płci i poziomu wykształcenia według Spisów Ludności z 2002 i 2011 roku (w \% ogółu emigrantów w danej grupie wieku)

\begin{tabular}{|c|c|c|c|c|c|c|c|}
\hline \multirow[t]{2}{*}{ Wiek } & $\begin{array}{l}\frac{E}{0} \\
\frac{0}{0} \\
0 \\
0\end{array}$ & \begin{tabular}{l}
$\mathbb{N}$ \\
.$N$ \\
\multirow{N}{*}{} \\
3
\end{tabular} & 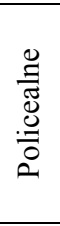 & $\begin{array}{l}\stackrel{0}{\Xi} \\
\stackrel{D}{D} \\
\dot{n}\end{array}$ & 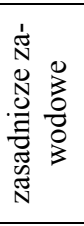 & 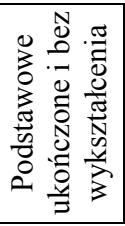 & 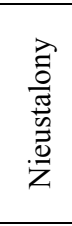 \\
\hline & \multicolumn{7}{|c|}{2002} \\
\hline $65-69$ & 100,0 & 5,7 & 1,4 & 14,3 & 13,1 & 28,5 & 36,9 \\
\hline $70-74$ & 100,0 & 4,3 & 0,6 & 10,4 & 10,3 & 34,1 & 40,3 \\
\hline $75-79$ & 100,0 & 2,8 & 0,4 & 8,0 & 8,3 & 36,7 & 43,9 \\
\hline $80-84$ & 100,0 & 2,7 & 0,5 & 6,8 & 5,3 & 37,3 & 47,4 \\
\hline \multirow[t]{2}{*}{85 lat i więcej } & 100,0 & 1,6 & 0,4 & 4,3 & 3,2 & 34,9 & 55,6 \\
\hline & \multicolumn{7}{|c|}{ Mężczyźni } \\
\hline $65-69$ & 100,0 & 8,3 & 0,6 & 10,7 & 18,7 & 21,5 & 40,2 \\
\hline $70-74$ & 100,0 & 6,9 & 0,5 & 10,3 & 14,3 & 23,7 & 44,3 \\
\hline $75-79$ & 100,0 & 5,2 & 0,3 & 8,0 & 14,1 & 24,6 & 47,8 \\
\hline $80-84$ & 100,0 & 5,9 & 0,6 & 7,0 & 10,5 & 26,5 & 49,5 \\
\hline \multirow[t]{2}{*}{85 lat $\mathrm{i}$ więcej } & 100,0 & 3,6 & 0,5 & 5,1 & 5,6 & 26,3 & 58,8 \\
\hline & \multicolumn{7}{|c|}{ Kobiety } \\
\hline $65-69$ & 100,0 & 4,0 & 2,0 & 16,8 & 9,3 & 33,3 & 34,7 \\
\hline $70-74$ & 100,0 & 2,6 & 0,7 & 10,5 & 7,8 & 40,8 & 37,7 \\
\hline 75-79 & 100,0 & 1,5 & 0,4 & 8,0 & 5,0 & 43,5 & 41,7 \\
\hline $80-84$ & 100,0 & 1,1 & 0,4 & 6,8 & 2,7 & 42,5 & 46,4 \\
\hline \multirow[t]{2}{*}{85 lat i więcej } & 100,0 & 0,7 & 0,4 & 3,9 & 2,2 & 38,5 & 54,3 \\
\hline & \multicolumn{7}{|c|}{2011} \\
\hline $65-69$ & 100,0 & 2,8 & 0,5 & 3,0 & 1,6 & 2,1 & 90,0 \\
\hline $70-74$ & 100,0 & 0,7 & 0,2 & 2,3 & 1,3 & 2,4 & 93,1 \\
\hline $75-79$ & 100,0 & 0,9 & 0,3 & 1,6 & 0,6 & 2,7 & 94,0 \\
\hline $80-84$ & 100,0 & 0,2 & 0,3 & 1,2 & 1,1 & 2,4 & 94,9 \\
\hline \multirow[t]{2}{*}{85 lat $\mathrm{i}$ więcej } & 100,0 & 0,4 & 0,0 & 0,2 & 0,0 & 2,3 & 97,2 \\
\hline & \multicolumn{7}{|c|}{ Mężczyźni } \\
\hline $65-69$ & 100,0 & 2,5 & 0,1 & 1,6 & 1,8 & 1,3 & 92,7 \\
\hline $70-74$ & 100,0 & 0,3 & 0,1 & 1,7 & 0,9 & 1,7 & 95,4 \\
\hline $75-79$ & 100,0 & 1,2 & 0,0 & 0,4 & 0,8 & 2,0 & 95,7 \\
\hline $80-84$ & 100,0 & 0,5 & 0,0 & 1,3 & 1,3 & 0,0 & 97,0 \\
\hline \multirow[t]{2}{*}{85 lat $\mathrm{i}$ więcej } & 100,0 & 0,0 & 0,0 & 0,3 & 0,0 & 0,0 & 99,7 \\
\hline & \multicolumn{7}{|c|}{ Kobiety } \\
\hline $65-69$ & 100,0 & 3,1 & 0,9 & 4,2 & 1,3 & 0,0 & 90,5 \\
\hline $70-74$ & 100,0 & 1,0 & 0,4 & 2,8 & 1,6 & 0,3 & 93,9 \\
\hline 75-79 & 100,0 & 0,8 & 0,4 & 2,4 & 0,5 & 0,2 & 95,7 \\
\hline $80-84$ & 100,0 & 0,0 & 0,4 & 1,1 & 1,0 & 0,6 & 96,8 \\
\hline 85 lat i więcej & 100,0 & 0,5 & 0,0 & 0,1 & 0,0 & 0,2 & 99,1 \\
\hline
\end{tabular}

Źródło: Opracowanie własne na podstawie (GUS 2003:212, 2013: 210). 
W odróżnieniu od ogółu osób emigrujących w wieku 13 lat i więcej, wśród których przeważały osoby z wykształceniem średnim, a następnie zasadniczym zawodowym, wśród starszych emigrantów większość legitymowała się wykształceniem podstawowym, w następnej kolejności średnim i zasadniczym zawodowym. W miarę przechodzenia do starszych grup wieku zwiększał się odsetek emigrantów z wykształceniem podstawowym. Różnice w poziomie wykształcenia starszych emigrantów widoczne były w przekroju według płci. W 2002 r. wyjeżdżający za granicę starsi mężczyźni byli zdecydowanie lepiej wykształceni niż kobiety po 65 roku życia. Rzadziej niż kobiety mieli wykształcenie podstawowe, częściej natomiast wyższe, zaś w 2011 r. - jak wskazują informację ze spisu - poziom wykształcenia emigrujących starszych kobiet podniósł się, częściej miały one wykształcenie wyższe i średnie niż starsi mężczyźni. Jednak biorąc pod uwagę ponad $90 \%$ odsetek braku informacji odnośnie do poziomu wykształcenia, trudno z całą pewnością stwierdzić, że w rzeczywistości mieliśmy do czynienia z wyraźną zmianą poziomu wykształcenia kobiet względem mężczyzn.

\section{Podsumowanie}

W niniejszym opracowaniu została podjęta próba przybliżenia problemu współczesnych migracji seniorów. Do tej pory nie został wypracowany uniwersalny wzorzec wyjaśniający w sposób kompleksowy to zjawisko. Przedstawione na początku opracowania teoretyczne modele, starające się wyjaśnić przyczyny i skutki migracji osób starszych, nie współzawodniczą z sobą wprost, lecz odwołują się do różnych perspektyw badawczych: ekonomicznej, demograficznej, społecznej i psychologicznej. Badacze szukający klucza opisującego prawidłowości migracji seniorów skupiają się na analizie przesłanek przemieszczeń, ich skutków w skali lokalnych społeczności oraz krajów, zarówno w krótkim, jak i długim okresie.

Starsi Polacy stanowią niewielki, względnie stały w ostatnich latach odsetek emigrantów. Pierwsza grupa obejmuje młodszych seniorów (którzy nie ukończyli 70 lat) i występujące $w$ niej migracje związane są z momentem przejścia na emeryturę, szukaniem wygodniejszego miejsca życia. Do drugiej subpopulacji należą osoby po 70 roku życia, które zaczynają mieć problemy zdrowotne, wymagają opieki lub zostają samotne. Na tym etapie życia niektórzy seniorzy przenoszą się w pobliże dzieci lub bezpośrednio do ich domów lub do domu pomocy.

W przypadku ludności po 65 roku życia, która uczestniczyła w migracjach zagranicznych przeważały osoby będące $\mathrm{w}$ związkach małżeńskich $\mathrm{w}$ przeciwieństwie do migracji wewnętrznych, w których głównie uczestniczyły osoby owdowiałe. Można zatem sądzić, że przemieszczenia zagraniczne miały charakter bardziej rodzinny niż wędrówki wewnętrzne osób starszych w Polsce. Jak 
wskazują wyniki Spisów Ludności z 2002 i 2011 roku osoby starsze, które przebywały za granicą to najczęściej małżeństwa bez dzieci, a w następnej kolejności małżeństwa $\mathrm{z}$ dziećmi, gdzie cała rodzina przebywa za granicą. W przypadku osób po 70. roku życia wyjeżdżających z Polski na stałe przeważały znacznie kobiety, gównie wdowy. Wskazuje to, że wśród najstarszych osób utrata małżonka, wymusza najczęściej przeprowadzkę do opiekunów rodzinnych [Szukalski 2002: 76].

Trudno przewidzieć, jaki będzie w przyszłości wzorzec migracji międzynarodowych polskich seniorów. Prowadzone badania w krajach Europy Zachodniej w tym zakresie wskazują na wzrost znaczenia przemieszczeń z północy na południe Europy. Integracja w ramach Unii Europejskiej sprawia, że upadło kilkanaście barier utrudniających ruchliwość przestrzenną w Europie. Wzrost niepełnosprawności na późniejszym etapie życia wydaje się być czynnikiem wystarczająco silnie zapobiegającym kontynuowaniu migracji zagranicznych. Serow, Friedrich i Haas (cyt. za: Longino, Bradley, 2001: 112), sugerują, że wzorzec migracji charakterystycznych dla seniorów z Wielkiej Brytanii (a dokładnie z Wielkiej Brytanii do Portugalii, Hiszpanii, Grecji i na Maltę) może również zaistnieć dla osób starszych w innych krajach europejskich. Postępujący proces starzenia się ludności w połączeniu ze wzrostem emigracji młodszych generacji nie pozostanie bez wpływu na kierunki i formy emigracji osób starszych z Polski.

\section{Bibliografia}

Baza danych Demografia, strona internetowa: http://demografia.stat.gov.pl/bazademografia, dostep: 10.11.2014.

Bean F. D, Myers G. C., Angel J. L., Galle O. R. (1994), Geographic concentration, migration, and population redistribution among the elderly, [in:] Marin L. G., Preston S. H., (ed.) Demography of aging, NAP, Washington, s. 319-356.

Bradley D. E., Longino Ch. F., Stoller E. P., Haas W. H. (2008), Actuation of Mobility Intentions Among the Young-Old: An Event-History Analysis, "The Gerontologist" Vol. 48, No. 2, 190-202.

Breuer T. (2005), Retirement Migration or Second-home Tourism? German Senior Citizens on the Canary Islands, Die Erde, 136 (3), p. 313-333.

Charles F., Longino Jr. (2001), Geographical distribution and migration, R. H. Binstock, L. K. Georgeds [w:] Aging and the Social Sciences, p. 103-213.

Colsher P. L., Wallach R. B. (1990), Health and other social antecedents of relocation in rural elderly person, "J. Gerontol" 45 (1).

Cuba L. J., Hummon D. M. (1993), A place to call home, Identification with dwelling community and religion, "Sociol" Q 34: 111-131.

Główny Urząd Statystyczny (GUS), (2003), NSP'2002, Migracje zagraniczne ludności, Warszawa.

Główny Urząd Statystyczny (GUS), (2013), NSP'2011, Migracje zagraniczne ludności, Warszawa.

Haas W. H., Serow W. J. (1993), Amenity retirement migration process: A model and preliminary evidence, "The Gerontologist", Vol. 33, 212-220.

Hogan, T., Steinnes, D., (1993), Elderly migration to the Sunbelt: Seasonal versus permanent, "Journal of Applied Gerontology" Vol. 12, No. 2: 246-260. 
Kałuża D. (2006), Migracje seniorów w Polsce, [w:] J.T. Kowaleski (red.), Ludzie starzy w Polskim Spoleczeństwie $w$ pierwszych dekadach XXI wieku, Wyd. Uniwersytetu Łódzkiego, Łódź, s. 151-172

Kałuża D. (2008), Migracje seniorów, [w:] T. Kowaleski, P. Szukalski (red) Starzenie się ludności Polski. Między demografia a gerontologia społeczna, Wyd. Uniwersytetu Łódzkiego, Łódź, s. $71-89$

Kałuża-Kopias D. (2011), Migracje seniorów w największych miastach w Polsce, [w:] T.J. Kowaleski (red.) Przestrzenne zróżnicowanie starzenia się ludności Polski, przyczyny etapy nastepstwa, Wyd. Uniwersytetu Łódzkiego, s. 69-107.

La Parra, D., Mateo M. A. (2008), Health status and access to health care of British nationals living on the Costa Blance, Spain, Ageing and Society, Vol. 28 No. 1: 85-102.

Latuch M., (1977), Przyczyny emigracji osób w starszym wieku z największych miast w Polsce, „Studia Demograficzne”, nr 50, s. 51-69.

Lawrence B. Schiamberg, Kathleen G. McKinney J., (2003), Factors Influencing Expectations to Move or Age in Place at Retirement Among 40- to 65-Year-Olds, "Journal of Applied Gerontology", Vol. 22 No. 19, p. 10-32.

Longino Ch. F., Bradley D. E. (2001), Geographical distribution and migration, [w]: R. H. Binstock, L. K. Georg (eds.), Aging and the Social Sciences, Oxford University Press, Oxford, 103-213.

Quandango J. (2002), Aging and the life course, Pepper Institute on Aging and Public Policy, Florida State University.

Rogers, A. (1990), Return migration to region of birth among retirement-age persons in the United States, "Journal of gerontology", Vol. 45 No. 3, s.128-134.

Rosset E. (1959), Proces starzenia się ludności. Studium demograficzne, PWG, Warszawa.

Steinnes D. N., Hogan T. D., (1992), Take the money and sun, Elderly migration as a consequence of gains in unaffordable housing market, "J. Gerontol", Von. 47, No.4: 197-203.

Stolarczyk K., (1985), Społeczno-ekonomiczne czynniki warunkujace migracje osób w starszym wieku w Polsce, ,Monografie i Opracowania”, SGPiS, Instytut Statystyki i Demografii, Warszawa, $189 \mathrm{~s}$.

Stolarczyk K. (1986), Społeczno-demograficzne aspekty migracji osób w starszym wieku, [w]: Witkowski J. (red.), Społeczno-demograficzne i ekonomiczne aspekty wspótczesnych migracji w Polsce, „Monografie i Opracowania”, SGPiS, Instytut Statystyki i Demografii, Warszawa, s. $106-123$.

Szukalski P. (2002), Przepływy międzypokoleniowe i ich kontekst demograficzny, Wyd. Uniwersytetu Łódzkiego, Łódź.

Uren Z., Goldring S. (2007), Migration trends at older ages in England and Wales, "Population Trends', No. 130, s. 31-41.

Walters W. H. (2006), Later-Life Migration in the United States, A Review of Recent Research, strona internetowa: htp://www.pineforge.com/ballantinestudy/articles/Chapter14_Article04.pdf dostęp: 10.07.2010.

Warnes A. M., Friedrich K., Kellaher L. and Torres S. (2004), The diversity and welfare of older, strona internetowa: http://eprints.whiterose.ac.uk/1515/1/warnes.a.m1.pdf dostęp:10.07.2010.

Wiseman, R. F. (1980), Why older people move theoretical issues. "Research on aging", 2 (2), $141-154$ 
Dorota Katuża-Kopias

\section{INTERNATIONAL MIGRATION OF OLDER POLES}

Abstract. The aim of this study is to identify the scale of Polish emigration of elderly residents in the twenty-first century. At the outset presented in the literature developed concepts explaining the mechanisms of migration of seniors. Analyzing the actual movement of seniors, the focus was mostly on the scale of emigration, and the main directions of movements. The analysis was based on data on permanent emigration from the country in the years 2002-2013 are available on the Central Statistical Office. The result of the analysis indicate that older Poles are small, relatively stable in recent years, the proportion of immigrants. Migrants seniors are most often those who are married, characterized by a low level of education.

Keywords: elderly migration, demography, migration. 